\title{
RELEVANSI SPIRITUALITAS KETUJUH JEMAAT DI KITAB WAHYU PADA JEMAAT KRISTEN DI GBT KAO NGALIYAN SEMARANG
}

\author{
Rudyanto Chandra Saputra \\ (Dosen Prodi Teologi: rudyantochs@sttkao.ac.id)
}

\begin{abstract}
The most sought spiritual attitude when he comes the second time, is loyalty, Loyalty to Faith is believed, which is demonstrated by continuing enthusiasm in serving His work on this earth. The fact that the church, the church of God, began to look weak in service, worship and other spiritual activities. The purpose of this study was to describe the relevance or similarity between the spirituality of the seven churches in the book of Revelation, which greatly degenerated its spirituality compare with the conggregation at the GBT KAO Ngaliyan Semarang. The results of hypothesis testing calculations, is that the comparison of $\mu_{0}$ values is $40 \%$ or equal to 72 , while the mean empirical score is 147.8 . Thus it is known that the hypothesis value $\left(\mu_{0}\right)$ or equal to 32 , is not the same as the empirical score value of 33.475. Or with other meanings the empirical score value is proven to be greater than the hypothesis value $\left(\mu_{0}\right)$. The 7th Spirituality Relevance Hypothesis in the book of Revelation to the conggregation of GBT KAO Ngaliyan is greater than or equal to $(\geq) 40 \%$ of the maximum value received and the 7 th Relevance of the Spirituality of the Church with the GBT KAO Ngaliyan congregation is less or not the same as $(<) 40 \%$ of the maximum value is rejected. Based on the calculation of the total score obtained the percentage value of spirituality relevance is $42 \%$ So, it can be said to be quite understanding. So, the spirituality of the seven churches in Revelation chapters 2 and 3 is not relevant to the spiritual attitudes of the GBT KAO Ngaliyan congregation in Semarang.
\end{abstract}

\section{A. PENDAHULUAN}

Penulis Kitab Wahyu ingin menekankan tentang keterlibatan Allah dalam urusanurusan manusia secara seksama. Penulis kitab ini adalah Yohanes (1:4); adakalanya dengan keterangan seperti: hamba (1:1) dan saudara dan sekutumu (1:9). Tetapi tidak ada keterangan rasul dan penatua. Waktu penulisannya diperkirakan sekitar tahun 93/95 M. ${ }^{1}$ Kitab Wahyu, dalam 3 (tiga) pasalnya yang pertama menunjuk pesan-pesan kepada tujuh jemaat di Asia Kecil. Keadaan mereka sangat dikenal oleh penulis Wahyu, dan anjurannya memang dibuatnya tepat untuk keadaan masing-masing jemaat itu. Dimana jemaat yang berdiri tegak, diberinya pujian (kepada Smirna dan Filadelfia). Dimana jemaat yang ada kekurangan, ditegur. ${ }^{2}$

Kitab Wahyu 2-3 menunjukkan bahwa Tuhan Yesus memberikan evaluasi terhadap gereja secara mendetail dan mengajak kepada pertobatan. Tuhan Yesus memberi perintah, peringatan dan janji kepada setiap gereja tersebut. Para ahli sependapat bahwa ada 3 cara untuk mempelajari isi dari ke dua pasal ini. Kitab Wahyu yang ditujukan kepada sekelompok jemaat di Asia, yang walaupun pesan yang ditujukan kepada jemaat-jemaat itu disampaikan secara terpisah-pisah dalam Wahyu 2 dan 3, namun jemaat-jemaat tersebut dianggap sebagai satu tubuh. Berdasarkan situasi itu, pokok utama dari surat-surat ini ialah kemurnian jemaat-jemaat dan penyerahan mereka kepada Kristus untuk menjadi Israel yang sejati. ${ }^{3}$ Surat-surat kepada ketujuh jemaat menggambarkan kondisi sebenarnya di setiap gereja pada akhir abad pertama. Tujuan ketiga dari surat-surat ini adalah untuk menyampaikan pelajaran universal yang

\footnotetext{
${ }^{1}$ Jhon Drane, Memahami Perjanjian Baru (Pengantar Historis-Teologis) (Jakarta: BPK-GM, 2003), 215-218.

${ }^{2}$ W.R.F. Browning, Kamus Alkitab (Jakarta: BPK-GM, 2009), 476.

${ }^{3}$ Donald Guthrie, Teologi Perjanjian Baru 3 (Jakarta: BPK-GM, 1993), 120.
} 
menggambarkan dan menangani kecenderungan manusia universal. Pemahaman yang diungkapkan surat-surat ini tentang Zaman Gereja - terutama era modern — dan bagaimana pelajaran itu berlaku bagi gereja dewasa ini.

Sumbangan utama yang dapat diperoleh dari Kitab Wahyu untuk pengertian mengenai jemaat adalah tentang ibadah. Ada banyak perikop dalam bentuk liturgi yang mengambarkan bentuk ibadah, yang dapat merupakan contoh yang baik untuk ibadah yang dilakukan dalam jemaat. Sebagian dari tujuh gereja ini lebih dekat kepada Injil daripada yang lain. Yesus memberi masing-masing "kartu laporan" singkat. Jemaat Efesus telah "meninggalkan cinta mula-mulanya," (Why. 2:4, ESV). Mereka kehilangan cinta mereka untuk Kristus, yang pada gilirannya mempengaruhi cinta yang mereka miliki untuk orang lain. Jemaat Smirna diperingatkan akan menghadapi penganiayaan. Yesus mendorong mereka untuk setia sampai mati dan dia akan memberi mereka mahkota kehidupan kekal. Pergamus diberitahu untuk bertobat. Tuhan Yesus mengatakan orang-orang yang menaklukkan godaan-godaan seperti itu akan menerima "manna tersembunyi" dan "batu putih", simbol-simbol berkat khusus. Tiatira memiliki nabi palsu yang menyesatkan orang. Yesus berjanji untuk memberikan diri-Nya (bintang pagi) kepada mereka yang menolak jalannya yang jahat. Sardis memiliki reputasi mati, atau tertidur. Yesus memberi tahu mereka untuk bangun dan bertobat. Mereka yang melakukannya akan menerima pakaian putih, namanya terdaftar di buku kehidupan, dan akan diberitakan di hadapan Allah Bapa. Filadelfia bertahan dengan sabar. Yesus berjanji untuk berdiri bersama mereka dalam pencobaan di masa depan, memberikan penghormatan khusus di surga, Yerusalem Baru. Laodikia memiliki iman yang suam-suam kuku. Para anggotanya merasa puas karena kekayaan kota. Bagi mereka yang kembali ke semangat semula, Yesus berjanji untuk membagi otoritas-Nya yang berkuasa. Yohanes menulis peringatan ini hampir 2.000 tahun yang lalu, namun masih berlaku untuk gereja-gereja Kristen hari ini. Kristus tetap menjadi Kepala Gereja di seluruh dunia dengan pengasih mengawasi gereja-gereja-Nya.

Gaya hidup jemaat masa kini kian tertular dengan apa yang terjadi di 7 (tujuh) gereja di Asia Kecil tersebut di atas. Gaya hidup adalah pola tingkah laku sehari-hari segolongan orang dalam masyarakat. Gaya hidup menyangkut cara hidup yang menjadi kebiasaan misalnya penampilan, makanan, relasi, cara bicara, cara mengatur keuangan dan sebagainya. Permasalahannya apakah gaya hidup orang Kristen masa kini selaras dan sejalan dengan gaya hidup Kristus atau kah sudah mulai terkena 'virus' yang dulu pernah ada di 7 jemaat tersebut di atas. Perlu disadari bahwa dunia menawarkan "gaya hidup" postmodern yang seringkali bertentangan dengan Alkitab. Dengan jelas Alkitab menyatakan bahwa sistem dunia ini dikuasai si jahat. Maksudnya dunia ini di bawah (dikuasai) tipu daya Iblis (dalam bahasa Yunani kata "dikuasai" adalah keitai yang artinya "di bawah penipuan").

Gaya hidup yang ditawarkan dunia dipengaruhi hedonisme, yang sangat menekankan kesenangan adalah sesuatu yang paling penting. Selanjutnya, materialisme juga menjadi tekanan. Uang dan kekayaan adalah segala-galanya, yang lain tidak perlu. Situasi sekarang ini, semua dihalalkan, yang penting ada uang dan kaya. Bahkan ke gereja saja yang dicari uang. Terakhir, gaya hidup duniawi menekankan sensualitas. Sensualitas sangat ditekankan dan dianggap sebagai "keterbukaan" dan modern. Mengenakan baju apabila tidak terlihat seksi dianggap kuno dan ketinggalan zaman. Pornografi dan pornoaksi ada dimana-mana dan seolah jadi barang 'biasa'. Bahkan ke gereja mengenakan pakaian serba terbuka dan ketat-ketat. Inilah gaya hidup yang ditawarkan dunia. Tentunya, gaya hidup yang duniawi ini seharusnya ditolak. Gaya hidup orang Kristen seharusnya berbeda dengan gaya hidup yang ditawarkan dunia ini. Alkitab menyatakan: "Jangan engkau serupa dengan dunia ini!" (Rm. 12:12). Kerohanian sejati 
sering memiliki manifestasi-manifestasi jasmani, tetapi kehadiran manifestasi-manifestasi jasmani tidak menjamin bahwa pengalaman rohani tersebut berasal dari Allah. ${ }^{4}$

\section{B. METODOLOGI}

Penelitian ini menggunakan metode deskriptif kuantitatif. Menurut Danim, studi deskriptif adalah alat untuk menemukan makna-makna baru, menjelaskan sebuah kondisi keberadaan, menentukan frekuensi kemunculan sesuatu, dan mengategorikan informasi. ${ }^{5}$ Sedangkan menurut Sukardi, "studi deskriptif ialah metode penelitian yang berusaha menggambarkan dan mengimplementasikan objek sesuai dengan apa adanya." Populasi pada penelitian ini adalah jemaat dewasa GBT KAO Ngaliyan Semarang. Populasi dalam penelitian ini berjumlah 40 orang. Metode pengumpulan data yang digunakan adalah metode kuesioner atau angket.

\section{PEMBAhASAN}

\section{Pengertian Spiritualitas}

Kata "spiritual" memiliki akar kata spirit yang berarti roh. Kata ini berasal dari bahasa Latin, spiritus, yang berarti napas. Selain itu kata spiritus dapat mengandung arti sebuah bentuk alkohol yang dimurnikan, sehingga spiritual dapat diartikan sebagai sesuatu yang murni. Dalam hubungan dengan pribadi (self), kata spiritual bisa diartikan sebagai energi kehidupan yang membuat kita dapat hidup, bernapas dan bergerak, ${ }^{7}$ termasuk pikiran, perasaan, tindakan dan karakter pada tataran konseptual. ${ }^{8}$ Berdasarkan pemahaman para ahli tersebut, disimpulkan bahwa spiritualitas sebenarnya adalah roh kita yang bisa diartikan sebagai energi kehidupan yang membuat kita hidup, bernapas dan bergerak, serta spiritualitas juga berarti segala sesuatu di dalam tubuh kita, termasuk pikiran, perasaan, tindakan dan karakter kita.

\section{Spiritualitas Kristen}

Spiritualitas bukanlah sesuatu yang asing bagi kebanyakan orang karena hampir setiap orang khususnya orang percaya mengerti dan melakukannya. Mutak dalam disertasinya mengatakan bahwa ada peningkatan dan pembaharuan baru tentang spiritualitas dan pembinaan rohani di kalangan Kristen hari ini. Hal itu dikarenakan spiritualitas merupakan bagian integral dari setiap orang percaya. ${ }^{9}$ McGrath pada bagian lain meyakini bahwa spiritualitas itu sudah diterima dan dimengerti secara luas sebagai praktik-praktik iman. Lebih lanjut dikatakan bahwa spiritualitas Kristen itu sebagai sebuah pencarian terhadap pemenuhan pengalaman hidup kekristenan yang melibatkan seluruh pengalaman hidup seseorang dalam ruang lingkup dimana 1995), 61 .

${ }^{4}$ Gerald R.McDermott. Mengenal 12 Tanda Kerohanian Sejati (Yogyakarta: Penerbit Andi,

${ }^{5}$ Sudarwan Danim, Riset Keperawatan: Sejarah \& Metodologi (Jakarta: EGC, “t.t”), 53.

${ }^{6}$ Sukardi, Metode Penelitian Pendidikan (Jakarta: PT Bumi Aksara, 2010), 157.

${ }^{7}$ Jr. Ralph W dan Krauss S. Hood, Religion, Spirituality, Conduct of life: Manners Customs, International Series in the Psychology of religion. Vol 16, 2013, 8-9.

${ }^{8}$ Stanford Stoyles dan Caputi Keating, A Measure of Spiritual Sensitivity for Children, International Journal of Children"s Spirituality. Vol. 17, No. 3 2012, 203-215.

${ }^{9}$ A. Areng Mutak. The Importance of Spiritual Formation in Equipping Evangelical Seminary Students in Malang Region Indonesia. Ed.D. Dissertation. Asia Graduate School of Theology, (Philippines: 2008), 43. 
ia berada. ${ }^{10}$ Karena itu spiritualitas Kristen harus dimengerti sebagai keseluruhan yang melibatkan seluruh eksistensi.

Spiritualitas yang benar adalah spiritualitas yang menekankan pada pembangunan relasi personal yang intim antara orang percaya dan Tuhan, serta memiliki konsep theologia yang valid serta menjalankan tanggung jawab sosialnya dalam konteks masyarakat dimana ia menjadi garam dan terang. Dalam menghadapi segala macam tantangan, krisis, dan kesulitan hidup orang percaya harus dapat mengembangkan spiritualitasnya.

\section{Latar Belakang Wahyu 2-3}

Tak dapat disangkal, Kitab Wahyu jarang dibaca dan kurang dimengerti oleh orang Kristen. Semua penafsir besar pada masa lampau merasa sulit memahaminya. Luther memandang Kitab Wahyu sebagai karya yang menyebalkan, dengan sedikit sekali keterangan tentang Kristus dan Calvin juga sangat menyangsikan nilainya. Banyak pembaca modern memiliki pandangan yang sama, dan menganggap pemberitaannya sebagai kemunduran ke jalan pemikiran Yahudi yang terburuk, yang berarti penyangkalan terhadap pemberitaan Yesus sendiri, ${ }^{11}$ sehingga sangat diperlukan penggalian yang dalam untuk memahami Kitab Wahyu.

Meninjau Kitab Wahyu secara seksama akan jelas terlihat bahwa penulisnya berpegang pada penekanan Kristiani yang positif tentang keterlibatan Allah dalam urusanurusan manusia. Walaupun bahasa dan gambar-gambar yang dipergunakannya berbentuk apokaliptik, pemberitaannya mempunyai penekanan yang sifatnya khusus Kristiani. ${ }^{12}$ Penerima kitab ini adalah ketujuh jemaat yang ada di Asia Kecil (1:4).

\section{Jemaat menurut Kitab Wahyu}

Sumbangan utama dari Kitab Wahyu untuk pengertian mengenai jemaat adalah tentang ibadah. Ada banyak perikop dalam bentuk liturgi yang mengambarkan bentuk ibadat pemujaan surgawi, yang dapat merupakan contoh yang baik untuk ibadah pemujaan yang dilakukan dalam jemaat. Sebetulnya, beberapa orang berpendapat bahwa perikop-perikop berbentuk liturgi ini berasal dari tata cara liturgi yang dipakai orang-orang Kristen Yahudi yang berbahasa Yunani. Hal yang tak dapat disangkal ialah, dariK Wahyu kita mendapat kesan bahwa penulisnya sangat menghargai ibadah pemujaan kepada Allah. Ia menceritakan tentang reaksinya yang penuh rasa hormat dan takut kepada waktu ia melihat Kristus yang dimuliakan (Why. 1:17). ${ }^{13}$

Surat kepada 7 Jemaat di Asia Kecil ini, tujuannya ialah memproklamasikan putusan yang berlaku kekal mengenai tingkah laku mereka. Di lain pihak $(1: 1 ; 4: 1)$, dalam penglihatanpenglihatan dengan bantuan bahasa kiasan tradisional, ia bermaksud menggambarkan hukum umum sejarah, sampai dengan kesudahannya. Penghiburan bagi mereka yang menderita demi iman, dan mengajak mereka bertekun sampai kemenangan akhir. Sebab Kerajaan Allah dan Anak Domba sudah merupakan kenyataan. Hanya saja para penganutnya masih harus mencapai akhir yang pada prinsipnya sudah dapat dipastikan mereka. ${ }^{14}$

\footnotetext{
${ }^{10}$ McGrath, E. Alister. Christian Spirituality: An Introduction. (Oxford: Blackwell Publishing, 2003), 2.

${ }^{11}$ Jhon Drane, 502.

${ }^{12}$ John Drane., 503.

${ }^{13}$ Donald Guthrie, Teologi Perjanjian Baru 3 (Jakarta: BPK-GM, 1993), 121.

${ }^{14}$ Nico Syukur Dister, Teologi Sistematika I (Yogyakarta: Kanisius, 2002), 38.
} 
5. Pemahaman Spiritualitas 7 Jemaat dalam Kitab Wahyu

Kesulitan-kesulitan yang diberikan kepada orang-orang Kristen di Asia diungkapkan secara rinci di sepanjang Kitab Wahyu. Mereka yang menolak untuk menyembah patung binatang (kaisar) terbunuh. Orang Kristen tidak bisa lagi membeli atau menjual kecuali mereka telah mengambil tanda binatang (Why. 13). Tekanan terhadap orang Kristen yang kaya untuk mempertahankan kekayaan mereka sangat kuat. Karena banyak sekali kekayaan Laodikia bergantung pada perdagangan, para pedagang Kristen berada dalam kebingungan. ${ }^{15}$ Ketujuh jemaat dalam Kitab Wahyu ini memberikan banyak prinsip teologis dan evaluasi kritis untuk mengembalikan kesadaran gereja-gereja di masa sekarang ini dalam menghadapi perkembangan pola berpikir dunia yang semakin tidak dapat dikompromi lagi dengan prinsip kebenaran Tuhan Yesus.

a. Jemaat di Efesus (Why. 2:1-7)

Berdasarkan bagian dalam perikop ini, ditekankan suatu peringatan bagi gereja-gereja dengan sebuah pertimbangan kritis tentang bagaimana sebuah gereja dapat melakukan hal-hal yang baik, tetapi menjadi tidak berdaya atau tanpa perasaan. Pemahaman biblikal berlaku untuk semua orang percaya ketika mereka merasa nyaman dengan hubungan mereka dengan Tuhan dan menerimanya begitu saja (gampang) dan terus menjalani hidup mereka seperti seolah-olah berada pada pusatnya. Ini indikasi bahwa orang percaya semacam ini ada dalam bahaya kehilangan cinta pertamanya. Kesimpulannya bahwa dengan melihat ke belakang, hal ini jelas membantu setiap orang percaya mengingat di mana mereka dahulu berada, ketika mereka mulai mengikuti Kristus. Saat mereka ingat, mereka akan kembali ke tempat keintiman dan cinta kepada Tuhan itu.

Membandingkan kitab atau kontras surat-surat ini - gereja dalam hal ini bukan bangunan melainkan pribadi, yang adalah komunitas orang-orang, di mana di dalam kasus Efesus, bukan hanya gereja yang kehilangan cinta mereka, tetapi juga orang-orangnya. Seiring waktu, orang dapat hanyut dalam hasrat mereka untuk Kristus dan dalam mengejar kasih orangorang percaya. Sebagian besar pengikut Kristus pada titik tertentu, pada situasi seperti ini sedang dalam perjalanan rohani mereka yang hanyut dan terhilang. Sementara, tantangan terbesar gereja ini adalah munculnya banyak guru-guru palsu yang menamakan dirinya rasulrasul. "Dalam masa hidup rasul Yohanes sudah muncul banyak guru dan nabi palsu, sebagian dari mereka justru berasal dari gereja-gereja." ${ }^{\prime 16}$ Hal itu tidak usah mengherankan, sebab Iblis pun menyamar sebagai malaikat Terang. Jadi bukanlah suatu hal yang ganjil, jika pelayanpelayannya menyamar sebagai pelayan-pelayan kebenaran. Kesudahan mereka akan setimpal dengan perbuatan mereka, namun demikian, jemaat Efesus adalah jemaat yang membuktikan dirinya mampu mengantisipasi guru-guru palsu yang memberikan otoritas pada ajaran-ajaran palsu mereka. Jemaat ini tidak memberikan ruang terhadap masuknya orang-orang dan ajaranajaran mereka ini untuk mempengaruhi pengajaran yang telah mereka terima dari para rasul sejati. $^{17}$

\footnotetext{
${ }^{15}$ Megan Sauter, "Bible History Daily: The Church of Laodicea in the Bible and Acrheology"; https://www.biblicalarchaeology.org/daily/biblical-sites-places/biblical-archaeology-sites/church-oflaodicea- in-the-bible-and-archaeology/ (diakses 10 September 2018) 2016), 30 .

${ }^{16}$ Stanley H. Morton, “Studi Perjanjian Baru: Eksposisi Kitab Wahyu” (Malang: Gandum Mas, ${ }^{17}$ Ibid., 31.
} 
Berdasar hal itu, jemaat ini memperoleh pujian dari Yesus. Menunjuk pada ayat 2-3 disebutkan bahwa orang-orang percaya di Efesus tanpa mengenal lelah menderita untuk Tuhan dan bertahan dengan tabah dan tekun, sabar menanggung sebab yang menghadang mereka, berjuang serta bekerja keras dalam berbagai kesulitan. Terbukti mereka tidak kehilangan semangat. Di lain hal, justru yang menyedihkan adalah kekurangan yang ditunjukkan oleh Tuhan, yaitu bahwa jemaat ini telah kehilangan kasih yang semula (ay. 4). Jadi, unsur-unsur kasih mula-mula ialah kesederhanaan dan kemurnian. Kasih gereja terhadap Tuhannya dilambangkan sebagai kasih seorang istri kepada suaminya. Lebih lanjut, kasih gereja kepada Kristus merupakan tanggapan dan ketundukan kepada kasih yang sempurna. Kasih yang semula adalah kasih pernikahan, yakni tindakan meninggalkan segala sesuatu. ${ }^{18}$ Issue ini menjadi persoalan yang pelik bagi gereja masa kini. Secara pengetahuan dan pengalaman hidup, pemahaman terhadap konsep kasih yang semula hampir tidak menjadi permasalahan yang berarti, namun dalam praktik kehidupan pribadi dengan berbagai macam tantangan zaman, maka dalam tahapan hidup kekristenan tertentu perlu ditinjau kembali.

\section{b. Jemaat Smirna (Why. 2:8-11)}

Gereja di Smirna ini adalah surat kedua dari 7 yang ditulis untuk gereja-gereja yang terletak di Asia Kecil pada akhir abad pertama. Smirna adalah salah satu dari dua gereja yang tidak menerima koreksi; sebaliknya, justru Yesus mendorong mereka. Di Smirna, menyembah Kaisar sebagai Tuhan adalah suatu cara untuk memastikan bahwa mereka memperoleh bantuan dari Roma. Ini jenis mentalitas patriotik yang bertolak belakang dengan kondisi sebaliknya yakni menolak untuk menyembah Kaisar yang mana hal itu berbahaya dan merupakan bentuk pengkhiatanan atau anti-patriotik. Namun, pengikut Yesus di Smirna mengklaim Yesus sebagai Tuhan, bukan Kaisar, dan mereka kehilangan segalanya sebagai balasannya. Mereka miskin, dikucilkan, dan dilecehkan. (ay. 9-10).

Mereka tahu bahwa iman mereka akan mengorbankan nyawa mereka. Perlu diperhatikan bahwa Yesus tidak memberi mereka teguran, namun hanya dorongan. Gereja Smirna hidup dalam kenyataan ini. Kelaparan, ketakutan, pengkhianatan, dan ancaman eksekusi terhadap mereka di setiap sisi. Ke dalam kenyataan ini, Kristus mengingatkan mereka bahwa harapan mereka tidak ditemukan di kedaulatan Kaisar, Roma atau kota mereka; itu semua ditemukan dalam diri-Nya. Perlu dipertimbangkan bahwa mereka menghadapi eksekusi, sementara Kristus dieksekusi di depan mereka dan kemudian bangkit dari kematian (1 Ptr. 3: 21-23).

Melihat pada Wahyu 2:9, di mana dinyatakan, "Aku tahu kesusahanmu dan kemiskinanmu namun engkau kaya dan fitnah mereka, yang menyebut dirinya orang Yahudi, tetapi yang sebenarnya tidak demikian: sebaliknya mereka adalah jemaah Iblis." Dalam iklim politik yang menuntut kesetiaan kepada Roma dan menyatakan Kaisar sebagai dewa, penderitaan harus terjadi dan dialami gereja ini. Di lain hal, meskipun Yesus mengakui kemiskinan mereka, dia tetap menyatakan mereka kaya. Ini terdengar seperti konflik. Kemiskinan, dalam teks bahas Yunani adalah ptocheia, yang memberikan makna miskin secara fisik, namun jemaat Smirna adalah orang-orang yang bermoral tinggi (taat beragama) dan kaya secara rohani. Orang Laodikia menganggap diri mereka makmur tetapi di mata Yesus bangkrut (Why. 3:17). Kemiskinan bukanlah tanda penghakiman Tuhan, tetapi itu adalah hasil sampingan dari hidup di dunia yang penuh dosa. Ini bukanlah suatu konsep "meromantiskan"

${ }^{18}$ G. Campbell Morgan, “A First Centuri Message to Twentieth Century Christians: Addresses on the Letters to the Seven Churches of Asia” (Baker Book House, 1980), 40-42. 
kemiskinan, tetapi seringkali mereka yang sangat sedikit hartanya terbukti memahami kebutuhan mereka.

Orang Kristen masa kini harus memahami bahwa meskipun mereka memiliki segala hal, misalnya, keluarga, pekerjaan, rumah, kesehatan, kekayaan, ternyata mereka masih perlu. Mereka membutuhkan Yesus. Dia adalah manna harian dan makanan mereka sehari-hari. Mereka setiap hari harus menyerahkan hati dan hidupnya kepada Yesus dan tidak meminta agar kehendak mereka sendiri dilakukan, tetapi itu dilakukan-Nya di dalam mereka dan melalui mereka. Orang Kristen masa kini bisa kehilangan semua miliknya, dan mungkin kemampuannya untuk mendapatkan lebih banyak, namun tantangan ini sanggup dihadapi ketika mereka bisa menemukan keamanan dalam kehidupan nyata (lih. Why. 2:10). Sementara, di lain hal juga ditambahkan, "Aku tahu kesengsaraanmu dan kemiskinanmu ... jangan takut" (Why. 2: 9-10). Dengan kata lain, seharusnya orang Kristen masa kini tahu apa yang mereka alami. Mereka mungkin saja akan menderita, tetapi jangan takut. Dan Yesus tampil secara terang- terangan, sementara Setan bersembunyi di balik pergumulan. "Jangan takut terhadap apa yang harus engkau derita. Sesungguhnya Iblis akan melemparkan beberapa orang dari antaramu ke dalam penjara supaya kamu dicobai dan kamu akan beroleh kesusahan selama sepuluh hari. Hendaklah engkau setia sampai mati, dan Aku akan mengaruniakan kepadamu mahkota kehidupan.” (Why. 2:10). Setan ingin meruntuhkan orang-orang percaya di Smirna sehingga mereka tidak lagi percaya, taat atau berbalik kepada Kristus; Si Jahat ingin melahap orang Kristen masa kini juga. "Sadarlah dan berjaga-jagalah! Lawanmu, si Iblis, berjalan keliling sama seperti singa yang mengaum-aum dan mencari orang yang dapat ditelannya." (1 Ptr. 5:8).

\section{c. Jemaat Pergamus (Why. 2:12-17)}

Menilik pada ayat 13 ditunjukkan bahwa Yesus meneguhkan jemaat. Bahan dasar pertimbangan ini bertumpu pada pertanyaan reflektif bagaimana rasanya hidup sebagai orang Kristen di kota ini. Hal-hal seperti perlunya koreksi, hidup toleransi, ajaran yang menyusup ke dalam gereja ini menjadi titik perhatian bagi pesan Yesus bagi penyelesaian masalah-masalah dalam jemaat ini sendiri. Yesus menegaskan Gereja ini karena mereka tidak akan menyangkal nama-Nya, bahkan di tengah tekanan budaya di sekitar mereka. Hidup sebagai orang Kristen pastilah sulit, terutama karena orang Kristen dianggap anti-patriotik dan dilihat dengan skeptisisme yang besar, namun, di lain pihak, mereka membiarkan ajaran palsu menyusup ke gereja mereka, dan karena itu mereka mulai berkompromi tentang kebenaran. Kemungkinan besar, mereka menghendaki gereja untuk menyembah tidak hanya Yesus, tetapi Kaisar. Apabila orang percaya masa kini melakukan hal demikian, maka mereka berisiko mengorbankan identitas mereka yang paling benar. Apabila hal tersebut dilakukan maka orang tersebut mengorbankan iman orang-orang percaya di dalam Kristus, dan dapat menenggelamkan hidup mereka.

Penyembahan berhala adalah memberikan sesuatu yang lebih menonjol, signifikan atau penting daripada Tuhan. Bahkan hal-hal yang baik, seperti keluarga Kristen, pekerjaan dan pelayanan di gereja. Hal-hal ini bisa menjadi penyembahan berhala ketika orang percaya masa kini mengangkatnya di atas pengabdian kepada Yesus. Immoralitas melibatkan aktivitas seksual yang melampaui apa yang Allah maksudkan dalam dan untuk hubungan manusia. 


\section{d. Jemaat Tiatira (Why. 2:18-29)}

Tiatira tampaknya terbagi menjadi dua yakni beberapa di antara mereka membutuhkan peringatan yang kuat, sementara yang lain menerima penegasan atas kesetiaan mereka. Tiatira dipuji karena mereka memiliki dedikasi yang sejati. Namun, mereka telah berkompromi di daerah kritis dalam kehidupan mereka, banyak yang tidak bermoral dan makan makanan yang dikorbankan untuk berhala (mereka memilih penyembahan berhala).

Gereja Tiatira jelas menegaskan iman mereka, pelayanan mereka dan cinta mereka. Dia juga menegaskan bahwa mereka telah memegang kesaksian mereka, yang belum terpengaruh oleh ajaran palsu. Mereka telah melakukan pekerjaan yang lebih besar dari sebelumnya, sehingga mereka tumbuh dengan disertai dampaknya. Faktanya, ini adalah kota yang sulit untuk ditinggali orang Kristen. Begitu banyak perdagangan dan pemerintahan di dunia kuno terkait dengan penyembahan berhala. Di Tiatira, secara khusus terkait dengan Apollo yang merupakan dewa matahari. Hal ini tampaknya telah memaksa mereka untuk berkompromi dan membiarkan perilaku seksual tidak bermoral menyebar di gereja. Tindakantindakan ini datang melalui nabi palsu. Ajaran yang salah sangatlah berbahaya bagi gereja. Mengenai pertanyaan bagi orang percaya masa kini, berhati-hatilah jika di berbagai tempat mulai ada sesuatu yang tidak pantas. Orang-orang di Tiatira tidak menghadapi bahaya agama kafir ataupun gaya hidup kafir. Mereka tidak juga di bawah tekanan penguasa atau bangsa Yahudi. Bencana untuk jemaat ini tidak datang dari luar tapi datang dari dalam. Seharusnya, kehidupan orang percaya masa kini berada dalam suatu perjalanan yang tidak statis. Artinya, misi mereka sebagai gereja atau jemaat adalah terus bertumbuh dalam iman dan dalam persaudaraan.

\section{e. Jemaat Sardis (Why. 3:1-6)}

Sardis memiliki reputasi kekayaan, kemakmuran dan budaya; tetapi setelah gempa bumi besar pada tahun 17M, apa yang mereka miliki kemudian berkurang dan akhirnya menjadi tidak ada. Mereka mencoba menopang reputasi mereka untuk kehidupan dan semangat, tetapi mereka mati dan bergantung pada Roma. Tampaknya gereja ini tidak kekurangan uang, sumber daya atau bakat. Mereka tidak mengalami penganiayaan serius, dan mereka tidak memiliki masalah dengan doktrin palsu. Di luar, semuanya tampak baik-baik saja - bahkan mungkin berkembang. Sebaliknya, Yesus berkata, "Aku tahu perbuatanmu; kamu memiliki reputasi hidup, tetapi kamu mati... Aku belum menemukan perbuatanmu lengkap " (Why. 3: 1-2). Ini tampaknya menjadi semacam bentuk tidur rohani - orang yang terlihat terjaga tetapi jiwanya sedang tertidur. Ketika orang percaya tidur secara rohani, hati mereka tertidur, meskipun pikiran dan tubuh bergerak. ${ }^{19}$ Yesus berkata, "Bangun!" Ia tidak hanya menginginkan energi jemaat; Dia ingin pengabdian di hati jemaat tumbuh kepada-Nya. Dia membenci ketika orang percaya melakukan sesuatu bahkan hal-hal yang baik hanya untuk terlihat baik bagi orang lain.

Berkaitan dengan kehidupan orang Kristen masa kini, maka terdapat kemungkinan bahwa ada orang Kristen duniawi di gereja masa kini. Orang Kristen yang memiliki Roh Kudus yang hidup di dalam mereka, tetapi mereka tidak lagi bergantung pada tuntunan Roh Kudus untuk menjalani kehidupan Kristen. Berdasarkan alasan apa pun, faktanya mereka menjalani kehidupan Kristen dengan kekuatan mereka sendiri sekarang. Mereka memegang kendali dan mereka tidak mengambil dari sumber daya itu (Roh Kudus). Kelompok ini akan menjadi stagnan secara rohani. Ayat 4 menunjukkan sebuah pengertian yang tepat untuk

${ }^{19}$ M. G. Easton, Easton's Bible Dictionary: Sardis, https: //www.biblestudytools.com. (diakses 14 September 2018). 
menggambarkan situasi ini bahwa ada beberapa yang "tidak mengotori pakaian mereka." Kata "kotor" di sini berasal dari kata Yunani é $\mu o ́ \lambda v v \alpha v$ (emolunan; Kata Kerja Indikatif Aorist Aktif Orang ke-3 Jamak dari kata dasar "moluno") yang berarti telah benar-benar menodai, mencemari dan mengotori. Secara harafiah, kata "mencemari" dalam ayat 4 ini berarti bahwa mereka semestinya hidup dengan cara yang benar. Sementara secara konotatif memiliki makna ketidaktaatan terhadap hukum agama, moral sehingga berdampak pada perilaku yang tidak bersih. ${ }^{20}$ Pakaian melambangkan karakter. Jadi, inti berita yang ingin disampaikan di sini adalah beberapa orang Kristen pada umumnya seharusnya tidak mengijinkan dunia mencemari mereka, yakni menodai karakter mereka.

Sejarah telah mencatat bahwa kota Sardis ini menjadi lemah dalam standar moral dan berujung menjadi tidak bermoral. Standar moral itu rupanya mulai merayap masuk ke dalam gereja. Ada beberapa yang pakaiannya, yang karakternya, tidak tercemar atau ternoda oleh benda-benda di sekitar mereka. Kelompok ini hidup secara spiritual, tetapi jumlah mereka hanya sedikit. Mereka adalah minoritas. "Tidak ada cukup dari mereka untuk mengubah keseluruhan evaluasi Kristus tentang gereja sebagai mati, tetapi Dia tidak melupakan mereka." ${ }^{21}$ Tuhan mengetahui bahwa ada banyak situasi semacam ini terjadi di gereja masa kini. Gereja yang sedang berada dalam situasi semacam ini ada dalam bahaya.

Gereja Sardis ada dalam bahaya kematian yang tidak dapat dikembalikan, dari keadaan dimana mereka tidak dapat dihidupkan kembali. Urgensitas yang menonjol di sini ialah jelas pesan untuk segera bertindak! Di samping itu, jelas pula adanya desakan yang mengindikasikan untuk segera dikerjakan. Kata "segera" di sini menimbulkan dugaan adanya waktu yang segera habis, dan dalam situasi atau waktu yang tepat, Tuhan Yesus kembali dan segera pula memberikan pesan dalam tulisan surat ini secara spesifik untuk mereka, "seperti pencuri" (Why. 3:3). Michael Wilcock mengatakan bahwa pengalaman Gereja Sardis membentuk gereja ini seperti benteng-Sardis, tidak akan pernah dapat diserang dan dianggap sulit untuk ditembus, tetapi justru lebih dari satu kali direbut dan ditawan oleh siluman. Orang Kristen masa kini dapat mencari cara dalam situasi yang sangat mendesak dengan menemukan pesan Tuhan sebagai jawaban.

\section{f. Jemaat Filadelfia (Why. 3:7-13)}

Gereja Filadelfia tidak begitu mudah diidentifikasi. Salah satu alasannya adalah pernyataan Yesus bahwa gereja ini hanya memiliki "sedikit kekuatan." Itu berpendapat bahwa orang percaya di gereja ini tidak besar jumlahnya namun sumber keuangan atau kekuatan pribadi besar. Ini menyimpulkan bahwa Philadelphians akan tersebar luas di seluruh komunitas Kristen. ${ }^{22}$ Wahyu 3: 8, Filadelfia telah "bekerja" dan telah "menuruti firman-Ku dan tidak mengingkari nama-Ku", jadi orang percaya dalam roh ini telah secara aktif menggunakan "kekuatan kecil" apa yang mereka miliki untuk melakukan Firman Allah dan menyatakan Yesus Kristus kepada dunia karena mereka mampu. Ini dibuktikan oleh kata-kata Kristus bahwa "Aku telah menetapkan di hadapanmu sebuah pintu yang terbuka, dan tidak seorang pun dapat menutupnya." Yesus telah melihat kemauan orang percaya ini untuk menggunakan sedikit kekuatan atau sumber daya apa yang mereka miliki dalam pelayanannya sehingga dia menetapkan di depan mereka sebuah "pintu terbuka" sehingga pekerjaan dan upaya mereka dapat berdampak dan menjangkau orang lain. Mungkin beberapa anggota gereja mendorong

\footnotetext{
${ }^{20}$ Friberg, Analytical Greek Lexicon, Bibleworks 10, CDSOFTWARE.

${ }^{21}$ Jong Yoon Kim, "Thesis: Charateristics Of A Healthy Church from The Seven Churches of Asia that Can Apply to Yohan Tokyo Christ Church", Lynchburg Virginia- 2006.

${ }^{22}$ John F. Walvoord. The Revelations of Jesus Christ (Chichago: Moody, 1966), 51.
} 
kepada hikmat atau kebijaksanaan daripada keberanian fisik, bahwa mereka harus menghindari masalah ketika keyakinan mereka bertentangan dengan budaya. ${ }^{23}$

Koreksi terhadap Gereja Filadelfia ini tidak diberikan; sebaliknya, Yesus justru memberikan penghiburan kepada mereka. Di tengah penganiayaan dan pertentangan yang hebat, dan dalam terang kebangiktan kembali komunitas Kristen ini, Yesus menawarkan penghiburan. Dalam kaitannya dengan Gereja Kristen masa kini, mungkin banyak gereja sekarang ini tidak mengerti semua yang Tuhan lakukan melalui "masalah" gereja setempat, tetapi gereja seharusnya mengerti bahwa Yesus menawarkan diri untuk menghibur gereja di tengah situasi yang menekan. Yesus juga berjanji bahwa "kita dapat menghibur mereka yang ada dalam bermacam-macam masalah dengan penghiburan yang kita terima dari Allah" (2 Kor. 1:3-7).

Kesimpulannya adalah bahwa ada banyak tempat di seluruh Alkitab di mana Allah meyakinkan umat-Nya bahwa Ia ada bersama umat-Nya. Inilah jaminan penghiburan Allah kepada umat-Nya yang percaya kepada-Nya. ${ }^{24}$ Lebih lanjut, gereja mampu membagikan semangat penghiburan dari Allah ini agar menggembirakan umat lainnya yang mengalami penderitaan. Mazmur secara umum mencatat tulisan-tulisan kudus dari berbagai orang percaya yang sedang mengalami pencobaan. Di sinilah orang-orang secara nyata dengan perjuangan mereka, keputusasaan, sakit hati dan semua emosi tidak dapat dihindari dalam kehidupan. Justru sebagian besar dari mereka bertekad dengan menunjuk kepada Allah sebagai sumber penghiburan di tengah-tengah pencobaan.

g. Jemaat Laodikia (Why. 3:14-22)

Jemaat di Laodikia penuh dengan jemaat yang puas diri. Mereka berkata, "Aku kaya dan aku telah memperkayakan diriku dan aku tidak kekurangan apa-apa" (Why. 3:17). Secara etimologis, kata "kaya" di sini bukanlah kata sifat, melainkan berasal dari kata Yunani $\pi \varepsilon \pi \lambda$ ov́ $\rceil \kappa \alpha$ (peplouteka; Kata Kerja Indikatif Perfek Aktif Orang ke-1 Tunggal dari kata dasar "plouteo"; artinya menjadi kaya). Ini menunjukkan dengan jelas bahwa mereka benar-benar secara materi berbicara. Keberadaan menjadi kaya ini membuat mereka merasa tidak butuh apaapa lagi. Keberadaan harta kekayaan mereka benar-benar sudah lengkap dan melimpah. ${ }^{25}$

Yesus menyerukan pertobatan dalam ayat 19 dan menindaklanjuti dengan undangan yang lembut di ayat 20. Makan merupakan aspek penting yang menunjukkan nilai persekutuan dan keintiman. Kepada mereka yang bertobat dan memiliki hubungan yang dekat dengan-Nya, Yesus menjanjikan tempat duduk di takhta surgawi (Why. 3:21). Yesus tidak hanya ingin menyelamatkan gereja, Dia ingin mengenal gereja-Nya. Frasa "ia akan Kududukkan bersamasama dengan Aku di atas takhta-Ku" berarti bahwa Kristus akan melimpahkan sebagian dari otoritas-Nya yang berkuasa kepada umat-Nya. ${ }^{26}$ Pesan penting dari Yesus muncul untuk memberikan perhatian serius pada respon gereja Laodikia terhadap masalah mereka di mana sikap tidak menerima penegasan apa pun akhirnya menjadi alasan yang mendasar gereja ini mendapatkan teguran keras. Ketika orang mulai beralih dari identitas dan nilai-nilai mereka, orang percaya termasuk gereja masa kini, menemukan dirinya pada situasi dan posisi kehilangan kesadaran. Jemaat Laodikia telah membuktikan hal ini. Mereka telah menjauh dari sauh Kristus dan karena inilah maka ia juga telah kehilangan pandangan tentang apa yang benar-benar penting.

\footnotetext{
${ }^{23}$ Ensiklopedia Alkitab, SABDA SOFTWARE.

${ }^{24}$ John Gill's Exposition of the Bible, https://www.biblestudytools.com/commentaries/gillsexposition-of-the-bible/revelation-3-7.html. (diakses 14 September 2018).

${ }^{25}$ Gingrich, Greek NT Lexicon, Bibleworks 10 CD SOFTWARE.

${ }^{26}$ ESV Study Bible, Bibleworks 10, CDROM SOFTWARE.
} 
Yesus menyebut mereka suam-suam kuku; ini adalah referensi tepat untuk menggambarkan tentang air. Mereka tahu kekuatan menyegarkan dari air dingin dan pembersihan dan kekuatan obat dari air panas. Sebagai perbandingan, maka air suam-suam kuku itulah air yang tidak berguna. Kata suam-suam kuku dalam bahasa Yunani adalah khliaros yang berarti tidak panas dan juga tidak dingin. Yesus menemukan ketidakpedulian-Nya yang hangat di gereja itu. Air dingin dan panas mewakili sesuatu yang positif, untuk menyegarkan air dingin, dan air panas adalah vitamin bagi yang dingin. ${ }^{27}$ Banyak orang Kristen di Laodikia mengkompromikan iman mereka sedemikian rupa sehingga penulis apokaliptik ini dapat mengatakan, "Aku akan memuntahkan engkau dari mulut-Ku." (Why. 3:16).

\section{Rangkuman Spiritualitas ke-7 Jemaat di dalam Kitab Wahyu}

Dari ketujuh jemaat tersebut, terlihat kekurangan dan kelebihan mereka. Ada yang ditegor, ada yang diperingatkan dan ada yang tetap setia.

$\begin{array}{ll}\text { Jemaat Efesus } & =\text { jemaat yang kehilangan kasih mula-mula } \\ \text { Jemaat Smirna } & =\text { jemaat yang teraniaya } \\ \text { Jemaat Pergamus } & =\text { jemaat yang berkompromi dengan dosa } \\ \text { Jemaat Tiatira } & =\text { jemaat yang hidup dalam kesesatan } \\ \text { Jemaat Sardis } & =\text { jemaat yang mati rohani } \\ \text { Jemaat Filadelfia } & =\text { jemaat yang setia } \\ \text { Jemaat Laodikia } & =\text { jemaat yang suam-suam kuku }\end{array}$

Kitab Wahyu ini berisi mengenai nubuatan yang akan terjadi. Begitu juga, ke-7 jemaat di dalam Kitab Wahyu ini juga melukiskan jemaat/gereja Tuhan yang ada pada akhir zaman ini.

Menurut salah seorang penginjil terkenal, Billy Graham, gambaran 7 jemaat di dalam Kitab Wahyu ini berisi 3 pengajaran pokok, yaitu:

1. Panggilan untuk mengasihi Tuhan seperti semula, hal ini ditujukan kepada jemaat Efesus dan Laodikia.

2. Panggilan untuk hidup benar, hal ini ditujukan kepada jemaat Pergamus, Tiatira dan Sardis.

3. Panggilan untuk bertahan dalam penderitaan, hal ini ditujukan kepada jemaat Smirna dan Filadelfia.

\section{HASIL PENELITIAN}

Dari penelitian terhadap 40 responden diperoleh hasil sebagai berikut:

\begin{tabular}{|l|l|l|l|l|l|}
\hline $\begin{array}{l}\text { Kelas } \\
\text { Interval }\end{array}$ & $\begin{array}{l}\text { Kategori } \\
\text { Kelas }\end{array}$ & Frekuensi & $\begin{array}{l}\text { Persentase } \\
(\%)\end{array}$ & $\begin{array}{l}\text { Batas bawah } \\
\text { nyata }\end{array}$ & $\begin{array}{l}\text { Batas atas } \\
\text { nyata }\end{array}$ \\
\hline $19-23$ & $\begin{array}{l}\text { Sangat } \\
\text { Rendah }\end{array}$ & 2 & 5 & 18,5 & 23,5 \\
\hline $24-28$ & Rendah & 7 & 17,5 & 23,5 & 28,5 \\
\hline $29-33$ & Rata-rata & 14 & 35 & 28,5 & 33,5 \\
\hline $34-38$ & Sedang & 7 & 17,5 & 33,5 & 38,5 \\
\hline $39-45$ & Tinggi & 10 & 25 & 28,5 & 45,5 \\
\hline T o t a 1 & & 40 & 100 & & \\
\hline
\end{tabular}

Tabel. 1

Tabel Frekuensi

\footnotetext{
${ }^{27}$ Noah Wiener, "Bible History Daily: Laodicea Columns Reveal the Grandeur of an Early Christian Center”, https://www.biblicalarchaeology.org/daily/biblical-topics/new-testament/laodiceacolumns-reveal-the-grandeur-of-an-early-christian-center/, (diakses 10 September 2018).
} 


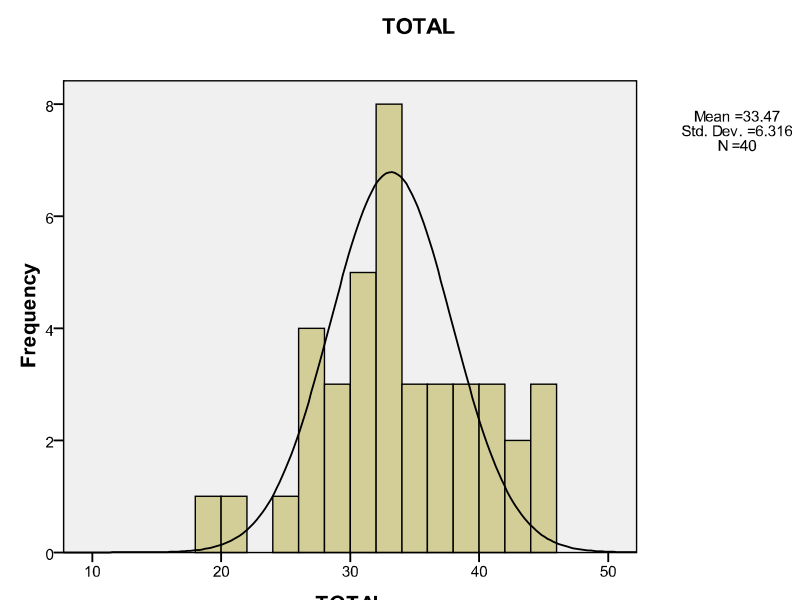

Gañibầr. 1

Histogram Frekuensi

Hipotesis penelitian ini merupakan hipotesis deskriptif dan penelitian ini merupakan penelitian populasi, sehingga uji hipotesis dilakukan dengan menggunakan nilai hipotesis yang diperoleh dari perbandingan nilai dengan rata-rata nilai empiris, kemudian untuk melihat nilai skor total dilakukan dengan cara skor empiris dibagi skor ideal dikali $100 \%$, sebab uji t tidak berlaku, untuk penelitian populasi.

Hasil hipotesis sebagai berikut:

Keterangan:

Nilai hipotesis

$$
=40 \%
$$

Skor Ideal

$=($ jumlah butir valid $) \mathrm{x}$ (skor tertinggi skala pengukuran) $\mathrm{x}$ (jumlah responden).

$$
\begin{aligned}
& =16 \times 5 \times 40 \\
& =3200
\end{aligned}
$$

Rata-rata skor ideal

$$
=(\text { skor ideal }):(\text { Jumlah responden })^{28}
$$$$
=3200: 40
$$

$=80$ (skor teoritis tertinggi)

Nilai Prosentase variabel

$$
\begin{aligned}
& =\frac{\text { skor Empiris }}{\text { Skor ideal }} \times 100 \% \\
& =\frac{1339}{3200} \times 100 \% \\
& =41,843=42 \%
\end{aligned}
$$

$\mu_{0}$

$$
\begin{gathered}
=(40 \%) \times 80 \\
=0,40 \times 80=32
\end{gathered}
$$

\footnotetext{
${ }^{28}$ Gidion, Research Methodology (Semarang: KAO Press, 2018), 79.
} 
Jadi nilai yang dihipotesis $\left(\mu_{0}\right)$ dari Relevansi Spiritualitas Ketujuh Jemaat di Kitab Wahyu pasal 2 dan 3 pada jemaat di GBT KAO Ngaliyan 40\% atau sama dengan 32. Selanjutnya dilakukan perhitungan nilai rata-rata (mean skor empiris), adapun hasilnya adalah 33, 475 (Total Skor Empiris : jumlah responden). Disimpulkan bahwa Relevansi Spiritualitas Ketujuh Jemaat di Kitab Wahyu pasal 2 dan 3 pada jemaat di GBT KAO Ngaliyan tidak sama dengan $(\neq)$ 40\% dari criteria yang ditetapkan. Nilai variabel Relevansi Spiritualitas bahkan lebih dari $40 \%$ dari yang diduga. Berdasarkan perhitungan diperoleh nilai relevansi spiritualitas sebesar 42\%. Relevansi Spiritualitas Ketujuh Jemaat di Kitab Wahyu pasal 2 dan 3 pada Jemaat di GBT KAO Ngaliyan lebih besar atau sama dengan ( $\geq$ ) 40\% dari nilai maksimum diterima dan Relevansi Spiritualitas Ketujuh Jemaat di Kitab Wahyu pasal 2 dan 3 pada Jemaat di GBT KAO Ngaliyan kurang atau tidak sama dengan $(<)$ 40\% dari nilai maksimum ditolak.

Berdasarkan perhitungan di atas diperoleh nilai persentase Relevansi Spiritualitas Ketujuh Jemaat di Kitab Wahyu pasal 2 dan 3 pada Jemaat di GBT KAO Ngaliyan adalah sebesar 42\%, maka nilai Relevansi Spiritualitas Ketujuh Jemaat di Kitab Wahyu pasal 2 dan 3 pada jemaat di GBT KAO Ngaliyan yaitu 42\% dapat diinterpretasikan cukup dipahami.

\section{E. KESIMPULAN}

Berdasarkan hasil dari penelitian yang dilakukan di Gereja Beth-El Tabernakel Kristus Alfa Omega Ngaliyan Semarang, dapat disimpulkan bahwa sebagian besar jemaat Gereja BethEl Tabernakel Kristus Alfa Omega Ngaliyan tidak mengalami kehilangan kasih mula-mula (1830 orang) yaitu berkisar $45-92 \%$. Hal itu ditunjukkan dari sikapnya yang tidak mau mengurangi pelayanan hanya dikarenakan hampir tidak memiliki waktu luang. Artinya mereka tetap bersemangat melayani walaupun harus mengorbankan waktu-waktu lainnya. Karena bersemangat dalam pelayanan, responden menyatakan tidak begitu mempedulikan ada atau tidak ada kawan sepelayanan. Namun, sebagian besar jemaat (21 orang) atau 52,5\% berpendapat bahwa mereka tidak mau ikut campur saat terjadi konflik atau adu mulut antar teman sepelayanan. Mungkin, beranggapan bahwa ikut campur bisa berpotensi memperkeruh keadaan. Jadi dapat disimpulkan kehilangan kasih mula-mula pada ketujuh jemaat di Kitab Wahyu tidak relevan dengan Jemaat Kristen GBT KAO Ngaliyan.

Perihal kestagnanan rohani seperti tersurat dalam spiritualitas ketujuh jemaat di Kitab Wahyu, 70-90\% jemaat di GBT KAO Ngaliyan tidak mengalaminya. Hal itu ditunjukkan dari jawaban kuesioner nomer 5-9 bahwa jemaat bisa menahan kemarahan yang meledak-ledak kepada sanak keluarganya (70\%), Mereka tidak setuju kalau dosa yang dilakukan dapat diganti dengan banyaknya aktivitas pelayanan (85\%), juga jemaat tidak haus akan pujian pada pelayanan yang telah dilakukan $(87,5 \%)$, serta juga tidak setuju jikalau pelayan Tuhan hanya datang beribadah di gereja saat tugas pelayanan saja $(72,5 \%)$, walau diakui ada beberapa jemaat yang maunya datang ibadah saat pelayanan saja. Hal itu bisa jadi dikarenakan kesibukan usaha dan mengurus anak dan rumah tangga. 92,5\% jemaat berpendapat tidak setuju jikalau semua pengurus harus mengikuti kehendak pribadi seseorang saja.

Aspek kompromistis yang dilakukan terhadap adat istiadat atau tradisi mistik keturunan (kejawen, dll), maka sebagian besar jemaat menghindarinya atau menolak godaan. Seperti misalnya pergi ke dukun untuk berobat, $80 \%$ menolak. Dalam hal menginjili kerabat, $62,5 \%$ jemaat lebih memprioritaskan melakukan penginjilan kepada kerabat yang belum Kristen daripada sekadar 'ewuh-pakewuh' dgn alasan keharmonisan. Juga mereka menyatakan bahwa pergi beribadah bukan sekadar upaya agamawi (72,5\%). Namun juga ada suatu kebutuhan untuk mengalami dan berjumpa dengan Tuhan lewat pujian-penyembahan juga firman-Nya. 
Relevansi rohani suam-suam kuku pada ketujuh jemaat di Kitab Wahyu juga tidak relevan dengan spiritualitas jemaat di GBT KAO Ngaliyan. Hal itu ditunjukkan dengan pernyataannya bahwa $72,5 \%$ tidak setuju bila acara RT/RW mengalahkan peribadahan. Sisanya mungkin tak mampu menghindar dari acara RT/RW dikarenakan sebagai pejabat (ketua RT/RW) harus memberi teladan untuk hadir di acara warga tersebut. Hal senada juga diungkapkan bahwa mereka memprioritaskan saat teduh bersama Tuhan $(92,5 \%)$. Hal itu juga dibuktikan dengan keengganan untuk meminta tukar jadwal pelayanan dikarenakan ada kesibukan pribadi (75\%). Beberapa mereka melakukan itu dengan anggapan tidak menjadi masalah asalkan yang diajak bertukar menerima dengan senang hati, namun itu dianggap suatu kekurangsadaran akan arti tanggung jawab di mata Tuhan. Sebagian besar jemaat (90\%) menyatakan ketidaksetujuannya apabila sampai datang terlambat saat latihan untuk pelayanan di mimbar.

\section{DAFTAR PUSTAKA}

Browning, W.R.F., Kamus Alkitab, Jakarta: BPK-GM, 2009.

Danim, Sudarwan . Riset Keperawatan: Sejarah \& Metodologi . Jakarta: EGC, "t.t".

Dister, Nico Syukur. Teologi Sistematika I, Yogyakarta: Kanisius, 2002.

Drane, Jhon, Memahami Perjanjian Baru (Pengantar Historis-Teologis), Jakarta: BPK-GM, 2003.

Gidion, Research Methodology. Semarang: KAO Press, 2018.

Gingrich, Greek NT Lexicon, Bibleworks 10 CD SOFTWARE.

Guthrie, Donald. Teologi Perjanjian Baru 3, Jakarta: BPK-GM, 1993.

Halim, Makmur . Gereja Di Tengah-Tengah Perubahan Dunia. Malang: Gandum Mas, 2003.

John Gill's Exposition of the Bible, https://www.biblestudytools.com/commentaries/gillsexposition-of-the-bible/revelation-3-7.html. Diakses 14-9-2018.

Kim, Jong Yoon. "Thesis: Charateristics Of A Healthy Church from The Seven Churches of Asia that Can Apply to Yohan Tokyo Christ Church", Lynchburg Virginia- 2006.

M. G. Easton, Easton's Bible Dictionary: Sardis, https://www.biblestudytools.com/dictionary/sardis/. Diakses 14-9-2018.

McDermott, Gerald .R.Mengenal 12 Tanda Kerohanian Sejati .Yogyakarta: Penerbit Andi, 1995.

Morgan, Campbell G. A First Centuri Message to Twentieth Century Christians: Addresses on the Letters to the Seven Churches of Asia. Baker Book House - 1980.

Morton. Stanley H. Studi Perjanjian Baru: Eksposisi Kitab Wahyu. Gandum Mas Malang2016.

Muntak, Areng.A. The Importance of Spiritual Formation in Equipping Evangelical Seminary Students in Malang Region Indonesia. Ed.D. Dissertation. Asia Graduate School of Theology, Philippines. 2008.

Sauter, Megan. "Bible History Daily: The Church of Laodicea in the Bible and Acrheology"; https://www.biblicalarchaeology.org/daily/biblical-sites-places/biblical-archaeologysites/church-of-laodicea- in-the-bible-and-archaeology/, Diakses 10 September 2018.

Stoyles, Stanford dan Caputi Keating, A Measure of Spiritual Sensitivity for Children, International Journal of Children"s Spirituality. Vol. 17, No. 3. 2012.

Sukardi, Metode Penelitian Pendidikan . Jakarta: PT Bumi Aksara, 2010.

Tafsir Adam Clarke.

W., Ralph Jr. dan Krauss S. Hood, Religion, Spirituality, Conduct of life: Manners Customs, International Series in the Psychology of religion. Vol 16, 2013.

Walvoord, John F. The Revelations of Jesus Christ . Chichago, Moody, 1966. 